\title{
Клініко-лабораторні, прогностичні критерії моніторингу перебігу гострого панкреатиту
}

\begin{abstract}
Мета роботи: розробити прогностичні критерії моніторингу перебігу гострого панкреатиту.
Матеріали і методи. Дослідження тривали із 2014 до 2018 р. ; за ступенем тяжкості ГП 167 пацієнтів були розділені на дві групи відповідно до Міжнародної консультації (2012р.). Проведено комплекс клінічних, загальних лабораторних обстежень та спеціальних, зокрема визначення рівня прокальцитоніну імунохроматографічним методом, інструментальні методи обстеження: комп’ютерна томографія (KT), ультразвукова діагностика (УзД), магнітно-резонансна панкреатохолангіографія. Проведено програмний аналіз отриманих даних в програмі StatisticaSoft 13.0., використано метод побудови нейронних мереж. Результати досліджень та їх обговорення. Встановлено, що рівень амілази понад 185 ОД / л і рівень АЛТ >34 - це показник, який вказує на ризик розвитку в пацієнта тяжкого або критичного панкреатиту. Прокальцитонін слід використовувати як маркер інфікованого гострого некротичного панкреатиту в комплексі з іншими параметрами запалення, що дозволяє вибирати правильне хірургічне лікування.
\end{abstract}

Ключові слова: гострий панкреатит; некротичний панкреатит; прокальцитонін; нейромережі.

Постановка проблеми і аналіз останніх досліджень та публікацій. Проблема панкреатиту має велике значення. Частота захворювання до 13 на 100000 населення, що становить близько $20 \%$ хірургічних хворих [11]. Приблизно кожний шостий випадок панкреатиту супроводжується ускладненнями, інколи з розвитком панкреонекрозу, смертність при якому становить до 80 \% [13]. У багатьох розвинених країнах кількість хворих на ГП за останні п’ятнадцять років подвоїлася, а це збільшує частку людей зі зниженою працездатністю, що зумовлює соціальне та економічне значення проблеми [5]. Загальна смертність від гострого некротичного панкреатиту (ГНП) і ураження заочеревинного простору до цих пір залишається дуже високою та в середньому становить $20 \%$ та 50 \% у стерильних та інфікованих ГНП [10]. Як в Україні, так і за кордоном не існує уніфікованого підходу до консервативного та хірургічного лікування ГНП. У літературних джерелах ми можемо знайти багато протиріч. Відбуваються все частіше дискусії щодо прогнозування перебігу ГП [9]. Неінвазивна діагностика інфікованого ГНП набуває актуальності [14]. Діагностична цінність при визначенні рівня прокальцитоніну в крові - біохімічного маркера сепсису, є недостатньо відомою.

Мета роботи: розробити прогностичні критеpiї моніторингу перебігу гострого панкреатиту.

Матеріали і методи. Дослідження тривали 3 2014 до 2018 р.; за ступенем тяжкості ГП 167 пацієнтів були розділені на дві групи відповідно до Міжнародної консультації (2012р.), яка є до- повненням Атланти (1992р.). Пацієнти з помірним ГП (наявність стерильного перипанкреатичного некрозу та/або недостатність органа) склали першу групу дослідження (n=98), до другої групи (n=69) ввійшли пацієнти з тяжким ГП (присутність панкреатичного некрозу і стійка органна недостатність) і критичний ГП (наявність інфікованого (пери) панкреатогенного некрозу та стійкої органної недостатності). Ступінь тяжкості визначали на підставі наявності місцевих детермінант, до яких належить панкреатогенний некроз та/або некрози перипанкреатичних тканин, що представлено терміном “(пери) панкреатогенний некроз”, а також системної детермінанти - наявність органної дисфункції, як наслідок ГП.

Проведено комплекс клінічних, загальних лабораторних обстежень та спеціальних, зокрема визначення рівня прокальцитоніну імунохроматографічним методом, інструментальні методи обстеження: комп'ютерна томографія (KT), ультразвукова діагностика (УЗД), магнітно-резонансна панкреатохолангіографія. Проведено програмний аналіз отриманих даних у програмі StatisticaSoft 13.0., а також метод побудови нейронних мереж.

Результати досліджень та ї обговорення. Серед обстежених із легким ГП було 45 хворих (26,94 \%), помірним ГП 53 (31,73 \%), тяжким - 43 (25,74 \%), критичним - 26 (15,56 \%) хворих. Середній вік пацієнтів склав $(44,6 \pm 1,05)$ року у першій дослідній групі та $(49,56 \pm 1,4)$ року у другій. Обстеження 167 пацієнта з ГП потребувало лабораторних і інструментальних методів, а також деяких спеціальних, особливо рівня прокальцитоні- 
ну в крові як маркера септичного запалення. Було проаналізовано 37 показників, що відображають стан окремих функціональних систем організму на 1, 2, 3, 7 добу захворювання. Після математич- ної обробки показників були вибрані 7 найбільш статистично достовірні показники 3 можливістю різниці ( $<0,05)$ : діастаза в сечі, амілаза, АСТ, АЛТ, білірубін, білок, глюкоза в крові (табл. 1).

Таблиця 1. Вміст окремих досліджуваних показників у хворих із гострим панкреатитом ( $\mathrm{M \pm м)}$

\begin{tabular}{||l|c|c||}
\hline \multicolumn{1}{|c|}{ Показники } & I група $(\mathrm{n}=98)$ & II група $(\mathrm{n}=69)$ \\
\hline Амілаза, U/L & $145,62 \pm 21,37$ & $298,16 \pm 43,7 * *$ \\
\hline Діастаза, U/L & $878,45 \pm 152,22$ & $1738,23 \pm 321,25^{* *}$ \\
\hline Глюкоза, $\mathrm{mmol} / \mathrm{l}$ & $7,2 \pm 0,21$ & $7,9 \pm 0,15$ \\
\hline Білірубін, $\mu \mathrm{m} / \mathrm{l}$ & $18,71 \pm 0,93$ & $28,15 \pm 1,78$ \\
\hline АЛТ, U/L & $34,61 \pm 1,25$ & $83,14 \pm 11,82^{* *}$ \\
\hline АСТ, U/L & $35,48 \pm 1,79$ & $74,73 \pm 11,32^{* *}$ \\
\hline Лейкоцити, х10 & $7,97 \pm 0,25$ & $13,26 \pm 0,57 *$ \\
\hline Гемоглобін,g/l & $115,27 \pm 1,88$ & $110,4 \pm 2,39$ \\
\hline Загальний білок, g/l & $60,37 \pm 0,29$ & $51,37 \pm 1,26 *$ \\
\hline \hline
\end{tabular}

Примітки:*- $<<0,05 ;$ ** $-\mathrm{P}<0,01$.

У статистичному аналізі отриманого матеріалу за допомогою тесту Стьюдента оцінювали ймовірність відмінностей цих параметрів у пацієнтів обох груп (табл. 1).

Лабораторні показники в різні дні хвороби представлені в динаміці на рисунках 1-5. Середні рівні амілази крові (рис. 1) та діастази сечі (рис. 2) в обох групах були найвищими в перший день захворювання і поступово зменшувались до третього дня. Спостерігали зниження навіть нижче рівня норми в II групі. Це необідно трактувати як прояви екзокринної недостатності залози через некроз паренхіми, що було підтверджено інтрапопераційно.

В обох групах спостерігається схильність до гіперглікемії (рис. 3), яка викликає тривогу як прояв порушення ендокринної функції підшлункової залози через запальний або запально-деструктив-

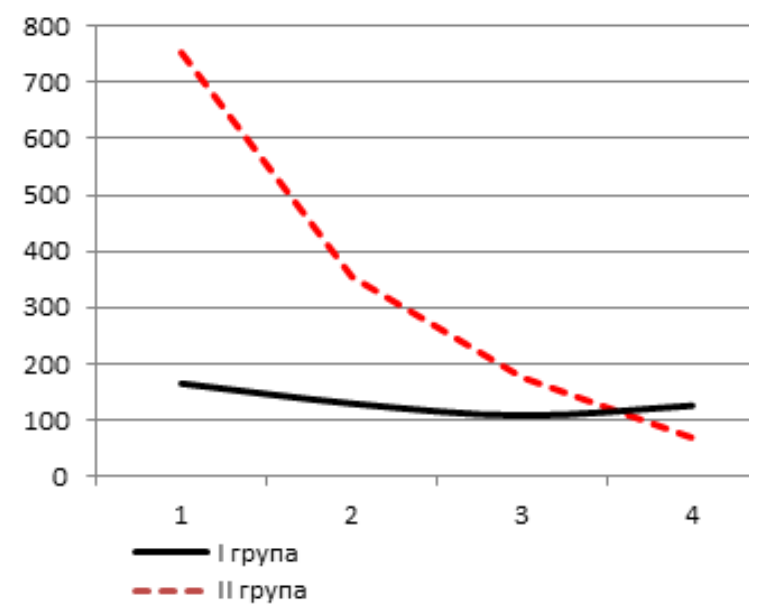

Рис. 1. Середні рівні амілази (Од/л) у пацієнтів I, II груп на 1, 2, 3, 7 доби.

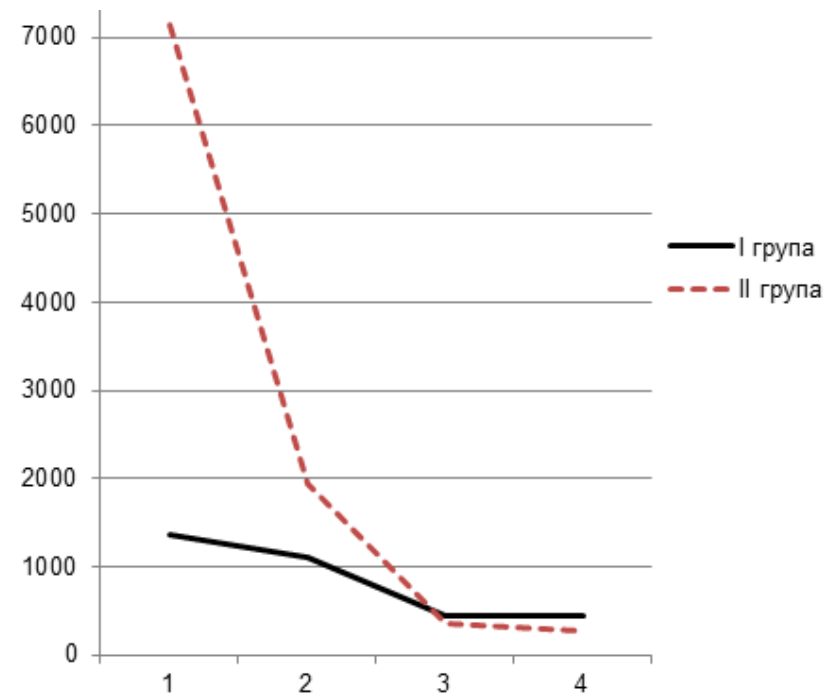

Рис. 2. Середні рівні діастази (Од/л) в пацієнтів I, II груп на 1, 2, 3, 7 доби.

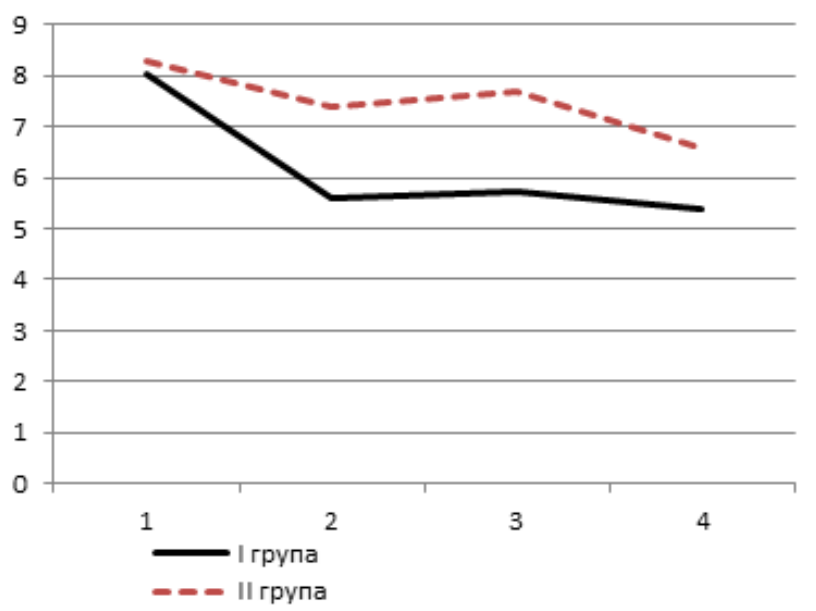

Рис. 3. Середні рівні глюкози крові (ммоль/л) у хворих I і II груп на 1, 2, 3, 7 доби. 
ний процес. Встановлено, що середні показники глюкози в крові були вищі порівняно з нормою в обох групах протягом перших семи діб спостереження. Це можна пов'язати із запально-деструктивними змінами підшлункової залози.

У пацієнтів II групи на момент перебування в лікарні був значний лейкоцитоз у крові (рис. 5), збільшення анемії в поєднанні з гіпопротеїнемією (рис. 6).

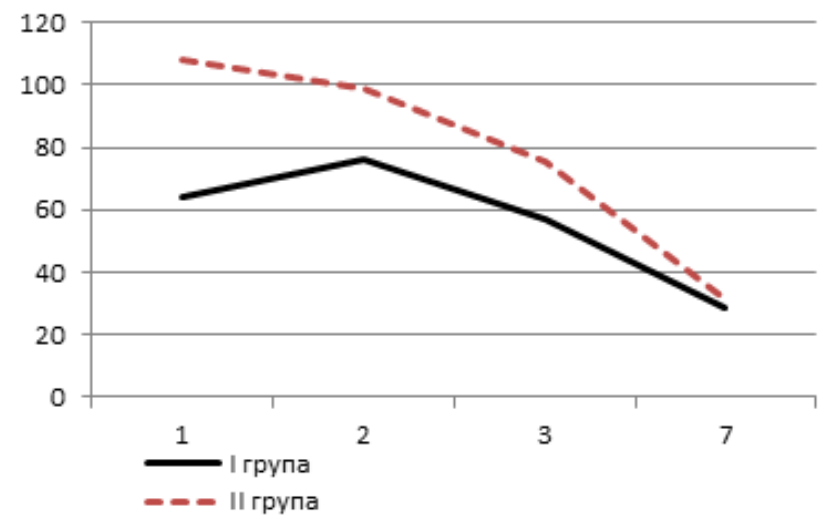

Рис. 4. Середні рівні АЛТ (Од/л) у пацієнтів I, II груп на 1, 2, 3, 7 доби.

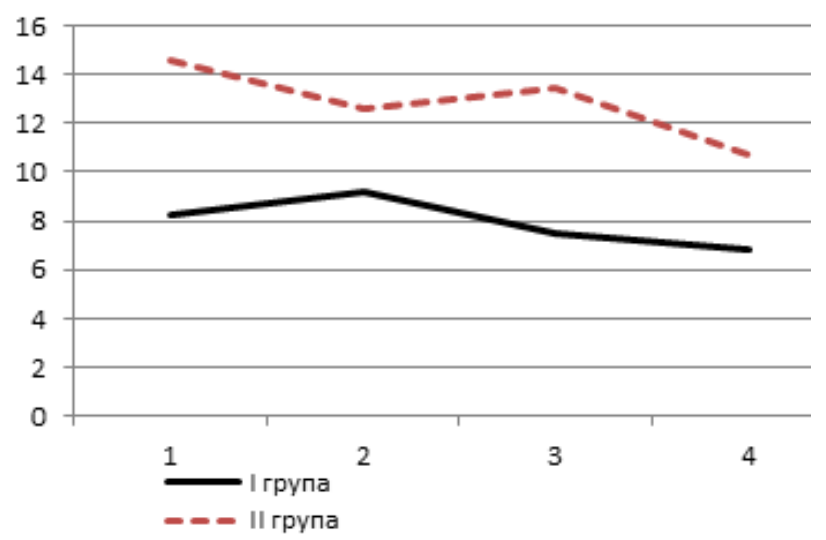

Рис 5. Середні рівні лейкоцитів х10 (9) в хворих I, II груп на 1, 2, 3, 7 доби.

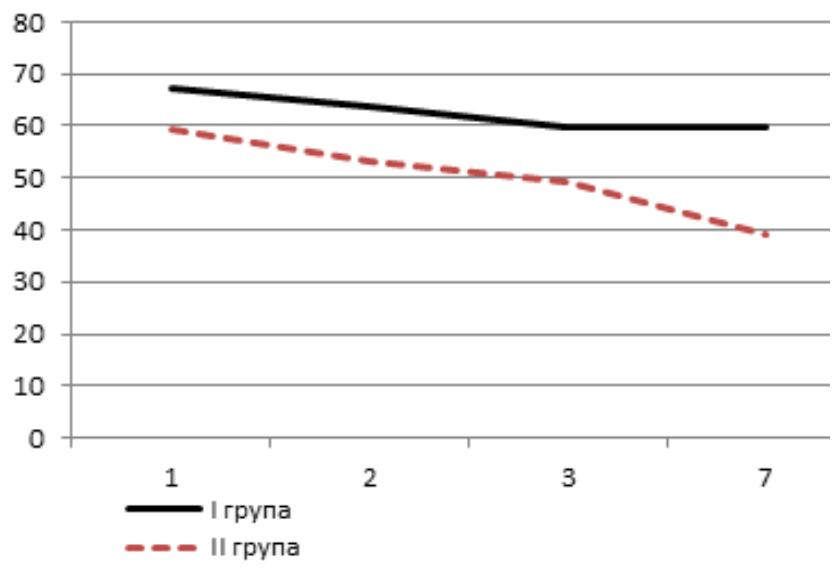

Рис. 6. Середні рівні загального білка (г/л) у хворих I і II груп на 1, 2, 3, 7 доби.
Тобто, для уточнення діагнозу переоцінюються лабораторні дані.Такі показники, як кількість білих кров'яних тілець, рівень діастази сечі, piвень прокальцитоніну, рівень глюкози в крові визначали в динаміці протягом щонайменше 7 діб, для подальшого встановлення взаємозв'язків, які би свідчили про їх діагностичну цінністть, як показників для ранньої діагностики ГНП.

Ми також проаналізували прокальцитонін як маркер септичного запалення. Високий рівень маркерів був у 12 пацієнтів (17,39 \%) II групи (тяжкі та критичні ГП), рівень маркерів був підвищений (> 2,0 нг/мл). У І групі (ГП легкої та середньої тяжкості) у 7 хворих був високий рівень маркерів $(7,14 \%)$. Всі хворі із високим рівнем ферменту були прооперовані, і в усіх випадках було встановлено наявність інфікованого ГНП. У 10 оперованих хворих I групи встановлено стерильний ГНП на основі низького рівня прокальцитоніну, їм виконано міні-інвазивне операційне втручання. Хворим із інфікованим ГНП виконано лапаротомію, яка підвердила доцільність інтраопрераційно у всіх випадках.

Наступним кроком для визначення прогностичних параметрів був значний кореляційний аналіз усіх цих критеріїв. Кореляційна матриця з'єднань для кожної групи пацієнтів складала 215 коефіцієнтів кореляції. Більшість зв'язків сформували такі чинники, як рівень діастази сечі, амілаза крові, рівні глюкози, корельовані один з одним та інші параметри системи. Зокрема, в перші дні кореляції між амілазою та діастазом були: $\mathrm{r}=$ 0,78 в I групі та $\mathrm{r}=0,76$ в II. На третю добу захворювання: $r=0,77$ i r $=0,74$ в I і II групах.

Для ранньої діагностики та прогнозування ГП ми зробили нейронну мережу (рис. 7) на основі кореляційного аналізу основних лабораторних та клінічних параметрів.

Слід зазначити, що тільки рівень крові амілази, діастази сечі та прокальцитоніну при надходженні корелює з тяжкістю панкреатиту. Розроблено “дерево рішень” на основі даних нейромережі (рис. 8).

Найбільш значущими параметрами були амілаза та АЛТ. Ризик пацієнта для участі у групі II (тяжкий та критичний панкреатит) був пов'язаний 3 рівнем амілази більше 185 Од/л та рівнем АЛТ> 34. Рівень амілази більше 185 Од/л - це чинник, який зумовлював ризик для пацієнта мати тяжкий або критичний панкреатит. Рівень ALT>34 був тим фактором ризику, і це пояснюється порушеннямиз боку печінки, тобто органною дисфункцією системного характеру. Сильні кореляції між амілазою та діастазою в першу добу захворювання: 


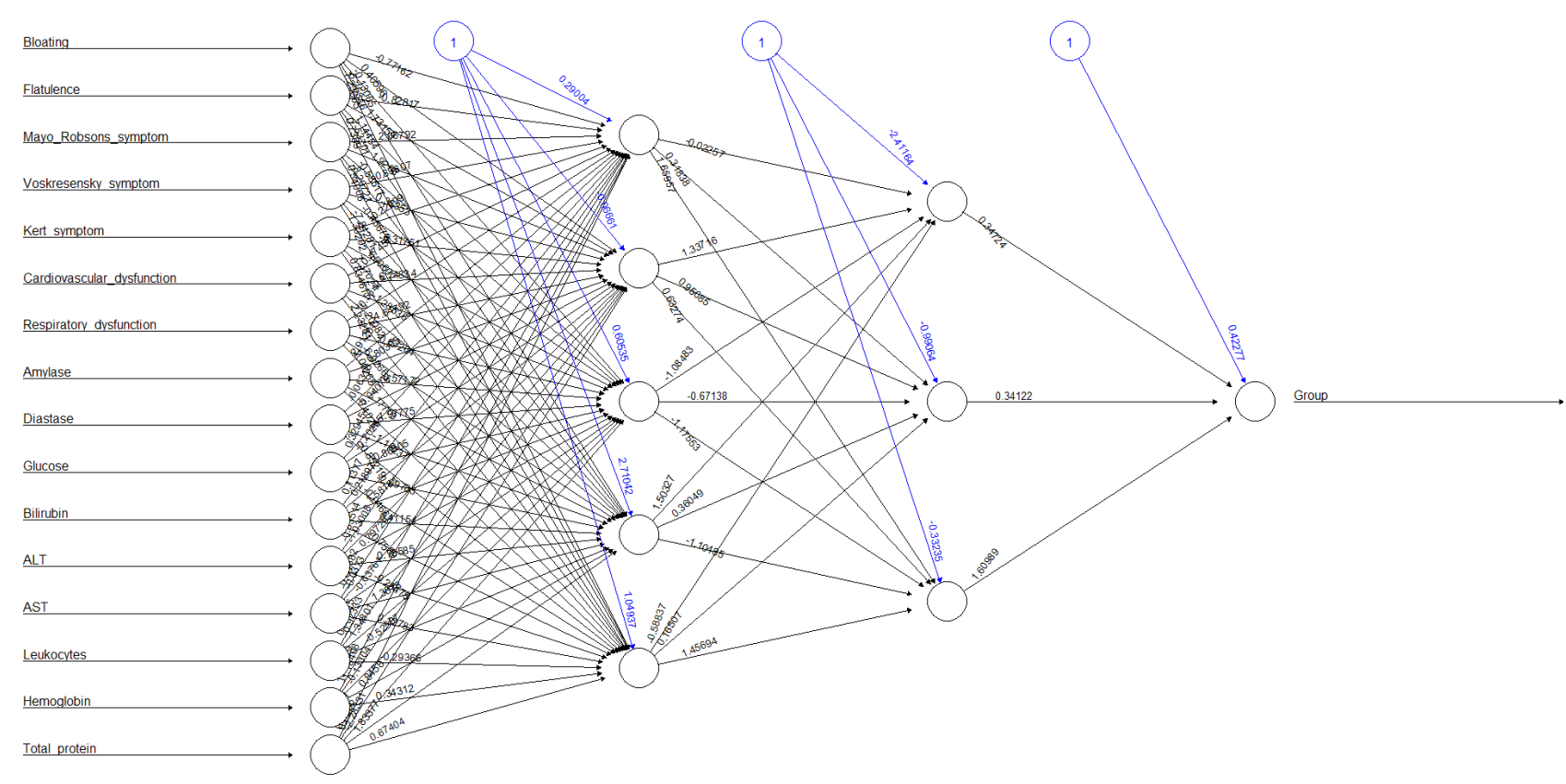

Рис. 7. Фрагмент нейромережі з взаємозв’язками між показниками.

Classification Tree for Pancreatitis

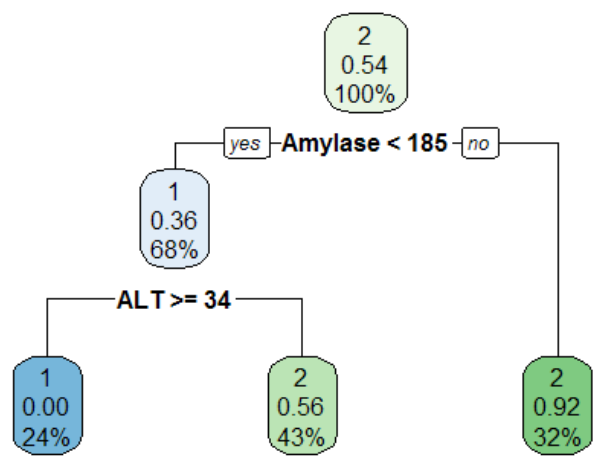

Рис. 8. Прогнозування ступеня тяжкості ГП за даними нейромережі ( “дерево рішень”).

$\mathrm{r}=0,78$ в I групі та $\mathrm{r}=0,76$ в II, на третій добу: $\mathrm{r}=$ 0,77 i r $=0,74$ в I і II групи показують значення цих параметрів при ранній діагностиці.

Ультрасонографія у хворих I групи виявила інформативні зміни підшлункової залози для ГП у 45 пацієнтів (45,91 \%) I та у 47 пацієнтів II групи (68,11 \%). Основні труднощі були пов'язані 3 симптомами здуття живота, особливо гіперпневматизмом поперечної ободової кишки та пацієнтами з надмірною масою. Отже, на першу добу від початку у пацієнтів із середнім, тяжким та критичим ГП діагностична цінність сонографічного діагнозу зменшується порівняно з легким ГП, що може призвести до помилок у діагностиці ГП. Комп’ютерну томографію проводили у пацієнтів із тяжким та критичним ГП і була цінна у 81,15 \% (56 хворих).
Висновки. 1. Встановлено, що рівень амілази понад 185 ОД / л і рівень АЛТ > 34 - це показник, який становить ризик розвитку у пацієнта тяжкого або критичного панкреатиту.

2. Прокальцитонін слід використовувати як маркер інфікованого ГНП у комплексі з іншими параметрами запалення, що дозволяє обирати правильне хірургічне лікування.

3. Діагноз гострого панкреатиту повинен грунтуватися на порівнянні клінічних симптомів та результатів інструментальних та лабораторних тестів.

4. Сильні кореляції між амілазою та діастазою свідчать про запальні зміни підшлункової залози, а швидке зниження на 3-ю добу навіть нижче рівня норми у групі II показує екзокринну недостатність через некроз паренхіми підшлункової залози.

5. Метод ультразвукового дослідження підшлункової залози має значення у близько половини пацієнтів I групи (45,91 \%), більшості II групи (68,11 \%), тоді як КТ є цінною у 81,1 5\% випадків при тяжкому та критичному панкреатиті.

Перспективи подальших досліджень. Нейронні мережі на основі кореляційних аналізів та “дерева рішень” показують результати, цінні для прогнозування та ранньої діагностики панкреатиту. Наші висновки грунтуються на порівняльному аналізі діагностичної цінності лабораторних та інструментальних методів діагностики у пацієнтів із ГП. Існує ще широка галузь досліджень прогнозування ГП, тому дослідження, які тривають 3 даної теми, повинні тривати. 


\section{СПИСОК ЛІТЕРАТУРИ}

1. Organ failure and infection of pancreatic necrosis as determinants of mortality in patients with acute pancreatitis / M. S Petrov, S. Shanbag, M. Chakraborty [et al.] // Gastroenterology. 2010. Vol. 139. - P. 813-820.

2. Petrov M. S. Conceptual framework for classifying the severity of acute pancreatitis / M. S. Petrov, J. A. Windsor // Clin. Res. Hepatol. Gastroenterol. 2012. Vol. 36. P. 341-344.

3. Petrov M. S. Infected pancreatic necrosis: not necessarily a late event in acute pancreatitis / M. S. Petrov, V. Chong, J. A. Windsor // World J. Gastroenterol. - 2011. - Vol. 17. - P. 31733176.

4. Введение в теорию нейронных сетей [електронний ресурс]: http://www.orc.ru/ stasson / neurox.html

5. Березницький Я. С. Оценка эффективности лечебных мероприятий при панкреонекрозе / Я. С. Березницкий, Н. А. Яльченко, Ю. Б. Капуста // Клінічна хірургія. - 2003. - № 1. - С. 5-6. 6. Бобров О. Е. Мифы и реальности панкреатологии: целесообразно ли использование антибиотиков в лечении больных острым панкреатитом / О. Е. Бобров// Хірургія України. 2008.-№ 4.- С. 71-81.

7. Дронов А. И. Сравнение шкал ВISAP, АРАCHЕ-II, RANSON'S в прогнозировании тяжести заболевания и летальности при остром панкреатите / А. И. Дронов, Т. В. Лубенец, К. С. Бурмич // Український журнал хірургії.- 2011. № 5(14).- С. 39-41.

8. Дронов А. И. Оценка эффективности методов экстракорпоральной детоксикации в лечении острого панкреатита /

\section{REFERENCES}

1. Petrov, M.S., Shanbag, S., \& Chakraborty, M. (2010). Organ failure and infection of pancreatic necrosis as a determinant of mortality in patients with acute pancreatitis. Gastroenterology, 139, 813-820.

2. Petrov, M.S., \& Windsor, J.A. (2012). Conceptual framework for the classification of acute pancreatitis. Clin. Res. Hepatol. Gastroenterol., 36, 341-344.

3. Petrov, M.S., Chong, V., \& Windsor, J.A. (2011). Infected pancreatic necrosis: not necessarily a late event in acute pancreatitis. World J. Gastroenterol., 17, 3173-3176.

4. Vvedenniya $\mathrm{v}$ teoriyu neyronnykh setey [Introduction to the theory of neural networks]. - Retrieved from: http://www.orc.ru/ [in Russian].

5. Bereznitskiy, Ya.S., Yalchenko, N.A., \& Kapusta, Yu.B. (2003). Otsenka efektivnosti lechebnykh meropriyatiy pri pankr eonekroze [Evaluation of the effectiveness of healing activities i n pancreatic necrosis]. Klinichna khirurhiia Clinical Surgery, 1, 5-6 [in Russian].

6. Bobrov, O.E. (2008). Mify i realnosti pankreatologii: tselesoobrazno li ispolzovanie antibiotikov v lechenii bolnykh ostrym pankreatitom [Myths and the reality of pancreatology: Is it advisable to use antibiotics in the treatment of patients with acute pancreatitis]. Khirurhiia Ukrainy Surgery of Ukraine, 4, 7181 [in Russian].

7. Dronov, A.I., Lubenets, T.V., \& Burmich, K.S. (2011). Sravneniye shkal BISAP, APACHE-II, RANSON\&apos;S v prognozirivanii tyazhesti i letalnosti pri ostrom pankreatite [Comparison of scales BISAP, APACHE-II, RANSON\&apos;S in predicting the severity of disease and mortality in acute pancreatitis]. Ukrainskyi zhurnal khirurhii Ukrainian Journal of Surgery, 5 (14), 39-41. [in Russian].

8. Dronov, A.I. (2005). Otsenka efektivnosti metodov ekstrakorporalnoy detoksikatsii $\mathrm{v}$ lechenii ostrogo pankreatitu
А. И. Дронов // Хірургія України. - 2005. - № 3. - С. 32-34. 9. Випадок успішного лікування хворого з важким деструктивним панкреатитом, ускладнений сепсисом / О. І. Дронов, Д. Б. Арешніков, Є. В. Дичаківський, А.М. Строкань // Біль, знеболювання і інтенсивна терапія. - 2007. - № 1. - С. 45-54. 10. Патогенетичний підхід до лікування гострого некротичного панкреатиту/ О. І. Дронов, І. О. Ковальська, В. Я. Шпак [та ін.] // Клінічна хірургія. - 2007.- № 9. - С. 25-27.

11. Дронов О. І. Гострий панкреатит: визначення, принципи діагностики та лікування / О. І. Дронов, І. О. Ковальська // Здоров’я України. -2010.-тематичний номер.- С. 28-29.

12. Антибактеріальна профілактика в лікуванні гострого некротичного панкреатиту. Медичні перспективи./ О. І. Дронов, І. Л. Насташенко, В. Ю.Уваров [та ін.] // Науковий журнал ДЗ “Дніпропетровська медична академія МО3 України.”- 2012.- Т.17, № 1.- С. 112-211.

13. Захараш М. П. Хірургія : підручник/ М. П. Захараш. -Вінниця : “Нова книга”,2014.-С.184-215.

14. Капшитарь А. В. Лапароскопия в оптимизации хирургической тактики у больних панкреонекрозом / А. В. Капшитарь // Український журнал хірургії. - 2011. - № 3 (12). C. 249-251.

15. Копчак В. М. Гострий некротичний панкреатит: сучасні підходи до хірургічного лікування / В. М. Копчак, І. В. Хомяк, К. В. Копчак [и др.] // Харк. хірург. школа. - 2008. - № 2. - C. 109-111.

[Evaluation of the effectiveness of extracorporeal detoxification methods in the treatment of acute pancreatitis]. Khirurhiia Ukrainy Surgery of Ukraine, 3, 32-34 [in Russian].

9. Dronov, O.I., Areshnikov, D.B., Dychakivskyi, \& Strokan, A.M. (2007). Vypadok uspishnoho likuvannia khvoroho z vazhkym destruktyvnym pankreatytom, uskladnenyi sepsysom [Case of successful treatment of a patient with severe destructive pancreatitis, complicated by sepsis]. Bil, znebolivannia $i$ intensyvna terapiia Pain, Anesthesia and Intensive Care, 1, 4554 [in Ukrainian].

10. Dronov, O.I., Kovalska, I.O., Shpak, V.Ya., Tsymbaliuk, V.Yu., R.S., \& Uvarov, V.Yu. (2007). Patohenetychnyi pidkhid do likuvannia hostroho nekrotychnoho pankreatytu [Pathogenetic approach to treatment of acute necrotic pancreatitis]. Klinichna Khirurhiia Clinical Surgery, 9, 25-27 [in Ukrainian].

11. Dronov, O.I., \& Kovalska, I.O. (2010). Hostryi pankreatyt: vyznachennia, pryntsypy diahnostyky ta likuvannia [Acute pancreatitis: definition, principles of diagnosis and treatment]. Zdorovia Ukrainy Health of Ukraine, 28-29 [in Ukrainian].

12. Dronov, O.I., Nastashenko, I.L., Uvarov, V.Yu., Nastashenko, O.I., \& Lubenets, T.V. (2012). Antybakterialna profilaktyka $\mathrm{v}$ likuvanni hostroho nekrotychnoho pankreatytu. Medychni perspektyvy [Antimicrobial prophylaxis in the treatment of acute necrotic pancreatitis. Medical perspectives]. Naukovyi zhurnal DZ "Dnipropetrovska medychna akademiia MOZ Ukrainy" Scientific Journal of the State Institution "Dnipropetrovsk Medical Academy of the Ministry of Health of Ukraine”,17 (1), 112-211 [in Ukrainian].

13. Zakharash, M.P. (2014). Khirurhiia: pidruchnyk [Surgery: Textbook]. Vinnytsia: "Nova knyha” [in Ukrainian].

14. Kapshitar, A.V. (2011). Laboratoskopiya v optimizatsii khirurgicheskoy terapii u patsiyentov pankreonekrozu [Laparoscopy in the optimization of surgical tactics in patients with 
pancreatic necrosis]. Ukrainskyi zhurnal khirurhii Ukrainian Journal of Surgery, 3 (12), 249-251 [in Russian].

15. Kopchak, V.M., Khomiak, I.V., \& Kopchak, K.V. (2008).

Hostryi nekrotychnyi pankreatyt: suchasni pidkhody do khirurhichnoho likuvannia [Acute necrotizing pancreatitis: modern approaches to surgical treatment]. Kharkiv. Khirurh. Shkola Kharkiv Surgeon School, 2, 109-111 [in Ukrainian].

Отримано 13.02.2018

\section{A. I. BANADYGA}

I. Horbachevsky Ternopil State Medical University

\section{CLINICAL-LABORATORY, PROGNOSTIC CRITERIA FOR MONITORING THE COURSE OF ACUTE PANCREATITIS}

The aim of the work: to develop prognostic criteria for monitoring the course of acute pancreatitis

Materials and Methods. The study was conducted from 2014 to 2018 on the severity of acute pancreatitis (AP) in 167 patients, who were divided into two groups according to the International Consultation (2012). The complex of clinical, general laboratory examinations and special tests was carried out, in particular determination of the level of procalcitonin by immunochromatographic method, instrumental examination methods: computed tomography (CT), ultrasound diagnostics (ultrasound), magnetic resonance pancreatic cholangiography. A software analysis of the obtained data in the program Statistica Soft 13.0 was carried out, the method of constructing neural networks was used.

Results and Discussion. It has been established that amylases above $185 \mathrm{U} /$ Land ALT $>34$ are a measure that raises the risk of developing a patient with severe or critical pancreatitis. Procalcitonin should be used as a marker of infected acute necrotic pancreatitis in combination with other parameters of inflammation, which allows you to choose the right surgical treatment.

Key words: acute pancreatitis; necrotizing pancreatitis; procalcitonin; neural network.

\section{А. И. БАНАДИГА}

ГВУз “Тернопольский государственный медицинский университет имени И. Я. Горбачевского МЗ Украины”

\section{К.ЛИНИКО-.ААОРАТОРНЫЕ, ПРОГНОСТИЧЕСКИЕ КРИТЕРИИ МОНИТОРИНГА ТЕЧЕНИЯ ОСТРОГО ПАНКРЕАТИТА}

Цель работы: разработать прогностические критерии мониторинга течения острого панкреатита.

Материалы и методы. Исследование длилось с 2014 по 2018 г.; по степени тяжести острого панкреатита (ОП) 167 пациентов были разделены на две группы в соответствии с Международной консультации (2012 г.). Проведен комплекс клинических, общих лабораторных исследований и специальных, в том числе определение уровня прокальцитонина иммунохроматографическим методом, инструментальные методы обследования: компьютерная томография (КТ), ультразвуковая диагностика (УзИ), магнитно-резонансная панкреатохолангиография. Проведен программный анализ полученных данных в программе Statistica Soft 13.0., использован метод построения нейронных сетей.

Результаты исследований и их обсуждение. Установлено, что уровень амилазы более 185 ЕД / л и уровень АЛТ> 34 это параметр, который представляет риск развития у пациента тяжелого или критического панкреатита. Прокальцитонин следует использовать как маркер инфицированного острого некротического панкреатита в комплексе с другими параметрами воспаления, что позволяет выбирать правильное хирургическое лечение.

Ключевые слова: острый панкреатит; некротический панкреатит; прокальцитонин; нейросети. 